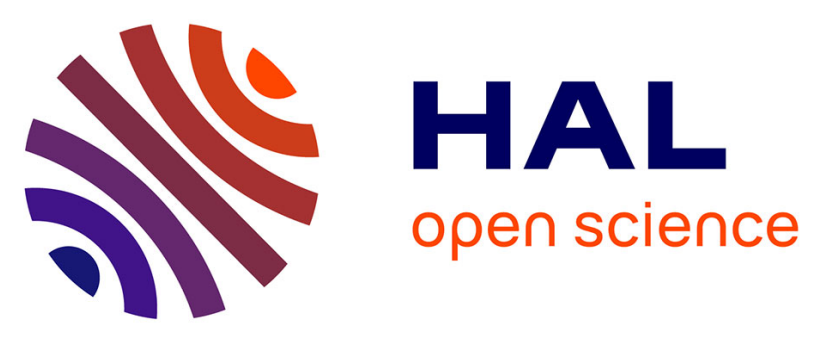

\title{
Both geometric morphometric and microsatellite data consistently support the differentiation of the Apis mellifera $\mathrm{M}$ evolutionary branch
}

Irati Miguel, Michel Baylac, Mikel Iriondo, Carmen Manzano, Lionel Garnery, Andone Estonba

\section{To cite this version:}

Irati Miguel, Michel Baylac, Mikel Iriondo, Carmen Manzano, Lionel Garnery, et al.. Both geometric morphometric and microsatellite data consistently support the differentiation of the Apis mellifera $\mathrm{M}$ evolutionary branch. Apidologie, 2011, 42 (2), pp.150-161. 10.1051/apido/2010048 . hal-01003582

\section{HAL Id: hal-01003582 \\ https://hal.science/hal-01003582}

Submitted on 1 Jan 2011

HAL is a multi-disciplinary open access archive for the deposit and dissemination of scientific research documents, whether they are published or not. The documents may come from teaching and research institutions in France or abroad, or from public or private research centers.
L'archive ouverte pluridisciplinaire HAL, est destinée au dépôt et à la diffusion de documents scientifiques de niveau recherche, publiés ou non, émanant des établissements d'enseignement et de recherche français ou étrangers, des laboratoires publics ou privés. 


\title{
Both geometric morphometric and microsatellite data consistently support the differentiation of the Apis mellifera $M$ evolutionary branch*
}

\author{
Irati MigueL ${ }^{1}$, Michel BAYLAC ${ }^{2}$, Mikel IRIONDO ${ }^{1}$, Carmen MANZANO $^{1}$, \\ Lionel GARNERY ${ }^{3,4}$, Andone ESTONBA ${ }^{1}$ \\ ${ }^{1}$ Department of Genetics, Physical Anthropology and Animal Physiology, Faculty of Science and Technology, \\ University of the Basque Country, 48940 Leioa, Spain \\ ${ }^{2}$ Muséum National d'Histoire Naturelle, CNRS UMR 7205 and UMS 2700, Plate-Forme Morphométrie, CP 50, \\ 45 rue Buffon, 75005 Paris, France \\ ${ }^{3}$ Laboratoire Évolution, Génomes et Spéciation, CNRS, avenue de la Terrasse, 91198 Gif-sur-Yvette Cedex, \\ France \\ ${ }^{4}$ Université de Versailles Saint-Quentin-en-Yvelines, UFR des sciences, 45 avenue des États-Unis, \\ 78035 Versailles, France
}

Received 26 November 2009 - Revised 3 April 2010 - Accepted 6 April 2010

\begin{abstract}
Traditional morphometrics, allozymes, and mitochondrial data have supported a close relationship between the M branch subspecies A. m. iberiensis and the North African subspecies (A branch). However, studies using nuclear DNA markers have revealed a clear distinction between the latter and the two European M branch subspecies. In help resolve this paradox, we analyzed 663 colonies from six European and African subspecies. A geometric morphometrics approach was applied to the analysis of wing shape, and the results were compared with data of six microsatellite loci. Both data sets were found to be highly consistent and corroborated a marked divergence of West European subspecies from North African ones. This supports the hypothesis that the presence of the African lineage mitotype in Iberian honey bee populations is likely the consequence of secondary introductions, with a minimal African influence within the current Iberian genetic background. Wing geometric morphometrics appears more appropriate than mitochondrial DNA analysis or traditional morphometrics in the screening and identification of the Africanization process.
\end{abstract}

honeybee / evolutionary branch / wing morphology / geometric morphometrics / microsatellite

\section{INTRODUCTION}

The honey bee (Apis mellifera) is naturally widespread throughout Africa, Europe, and Western Asia. Based on morphometric measurements, different subspecies have been identified and grouped into four major evolutionary branches (Ruttner et al., 1978; Ruttner, 1988): the A (Africa), M (Western Europe), C (South-Eastern Europe), and O (Middle

Corresponding author: I. Miguel, irati.miguel@ehu.es

* Manuscript editor: Marina Meixner
East) branches. This classification was largely supported by mitochondrial studies (Garnery et al., 1992; Arias et al., 1996; Franck et al., 2000), which revealed an additional fifth evolutionary branch, called Y (Yemenitica from Ethiopia; Franck et al., 2001). However, controversy still exists over the differentiation of the $\mathrm{M}$ branch and the North African A branch populations, and more specifically, over the relationship between the subspecies $A$. $m$. intermissa (A branch), A. m. mellifera (M branch from North-Western Europe), and A. $m$. iberiensis ( $\mathrm{M}$ branch from Iberian Peninsula). 
Western Europe and North Africa are contact regions for the $\mathrm{A}, \mathrm{M}$, and $\mathrm{C}$ evolutionary branches. Using a wide set of morphological characters - related to body and wing distances, ratios and angles, color, and pilosity Ruttner et al. (1978) highlighted the morphological affinity between the Iberian honeybee, A. $m$. iberiensis, and the North African, A. $m$. intermissa, describing a clinal variation $A$. $m$. intermissa- A. m. iberiensis- A. m. mellifera subspecies. Based on these results, they hypothesized a progressive transition linking the $\mathrm{M}$ branch with the North African A branch via the Iberian Peninsula. Subsequently, Cornuet and Fresnaye (1989) analyzed six of Ruttner's morphological characters in the Iberian bees, and their results supported this idea. However, it must be pointed out that Arias et al. (2006) analyzed 23 morphometric characters, mainly from the wing, and detected a discontinuity between European and North African populations, questioning the previously described close relationship between them.

Regarding genetic data, the North Africa Europe morphological gradient was supported by a parallel cline at the malate dehydrogenase (MDH) locus from Morocco to France through the Iberian Peninsula, but this cline was not supported by another allozyme marker - phosphoglucomutase (PGM) - (Smith and Glenn, 1995; Arias et al., 2006). Mitochondrial studies of the honey bee populations of the Iberian Peninsula also detected a south-western to north-eastern clinal transition from the African A lineage to West European M mitochondrial lineage (Smith et al., 1991; Arias et al., 1996, 2006; Garnery et al., 1995, 1998a; Franck et al., 1998; Miguel et al., 2007; Canovas et al., 2007). This mitotype cline, together with the high divergence detected between $\mathrm{A}$ and $\mathrm{M}$ mitochondrial DNA lineages, led Smith et al. (1991) to propose a hybrid origin of Iberian populations after secondary contact between A. m. intermissa and A. m. mellifera. Nevertheless, studies based on microsatellite loci (Franck et al., 1998, 2001; Garnery et al., 1998b) did not support a hybrid origin for the A. m. iberiensis subspecies. On the contrary, they showed a close genetic resemblance between the two European subspecies of the M branch and a clear break between them and all the analyzed Africans subspecies, including A. m. intermissa. Recently, a study based on single nucleotide polymorphisms (SNPs; Whitfield et al., 2006) revealed a marked differentiation between all branches described by Ruttner (1988). They detected major differences between the $\mathrm{A}$ and $\mathrm{M}$ branches, although the differences were smaller than those between the $\mathrm{M}$ and $\mathrm{C}$ branches. The North African populations were grouped close to the rest of the African populations, far from western European ones.

In short, phylogeographic studies based on traditional morphological data and those based on genetic data are largely consistent in terms of their description of the evolutionary branches of Apis mellifera. However, these studies are not in agreement concerning the differentiation between the $\mathrm{M}$ branch and North African populations. Moreover, discrepancies among morphological studies, among genetic studies, and between these two empirical approaches abound regarding this matter.

Since its initial development (Bookstein, 1991), geometric morphometrics has been shown repeatedly to have better descriptive and higher statistical power than traditional morphometrics (c.f. Monteiro et al., 2000; Adams et al., 2004). In insects in general (Baylac and Daufresne, 1996; Baylac and Penin, 1998; Klingenberg et al., 2001; Baylac et al., 2003) or in honeybees in particular, geometric morphometric analyses of wing shape have provided many new insights, either into the characterization and identification of populations or lineages (Baylac et al., 2008; Tofilski, 2008), the Africanization process of American populations (Francoy et al., 2008, 2009), or even into the more demanding analyses of heritability (Monteiro et al., 2002) or individual wing asymmetry (Smith et al., 1997; Klingenberg et al., 2001). When molecular and geometric morphometrics results were compared, a close congruence was generally observed, with exceptions being almost always related to differential selective pressures (Marroig and Cheverud, 2004; Hamon and Gibson, 2006; Evin et al., 2008).

The goal of this work was to contribute to resolving the controversy that currently exists regarding differentiation between the $\mathrm{A}$ and 
M evolutionary branches. To this end, a wide sample of populations from six subspecies of Apis mellifera (two for each evolutionary branch A, M, and C) were analyzed, applying two different approaches: geometric morphometrics analysis of wing shape variability and microsatellite analysis.

\section{MATERIALS AND METHODS}

\subsection{Geometric morphometrics: data acquisition and treatment}

A total of 663 colonies (one honeybee per colony, preserved in absolute alcohol) from 27 populations of $A$. mellifera were sampled for the geometric morphometrics analysis (Tab. I): 18 from the Iberian Peninsula (A. m. iberiensis), five from France and Belgium (A. m. mellifera), and four populations of subspecies $A$. m. intermissa and $A$. $m$. major from branch A and A. m. ligustica and A. $m$. macedonica from branch $\mathrm{C}$.

Coordinates of 19 landmarks located on the fore-wing (Fig. 1), identical to those already used by Smith et al. (1997), were measured using a video camera $(768 \times 512$ pixels $)$ connected to an AT-OFG frame-grabber and MeasurementTV software (Updegraff, 1990). Wings were temporarily mounted in distilled water. Water in excess was gently absorbed in order to ensure the flatness of the wing membrane onto the slide. Each wing was measured twice and the two measurements were averaged in order to reduce the measurement error. Raw coordinates of the landmarks were superimposed using a Procrustes generalized least-squares (GLS) superimposition algorithm (Rohlf and Slice, 1990): the sum of squared distances between homologous landmarks of each object and a reference configuration are iteratively minimized by translations and rigid rotations. At each iteration, the reference taken as the mean configuration of the whole superimposed sample is updated. Centroid size, defined as the square root of the sum of the squared distances between the centre of the object and its landmarks (Bookstein, 1991), is eliminated from the superimposed coordinates by ratios. Geometrically, each object is therefore scaled to unit centroid size, centered, and rotated in order to minimize its deviations from a reference object. At the end of the superimposition process, the whole dataset is represented by (1) a vector of centroid sizes, (2) the coordinates of the reference object or consensus, and (3) a matrix of shape parameters that correspond to

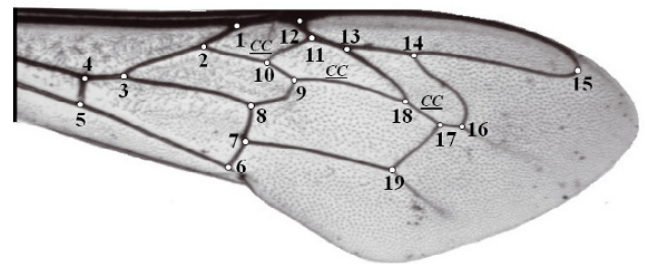

Figure 1. Location of the nineteen landmarks on the fore-wing of honeybee workers considered in the geometric morphometric analysis $(\mathrm{CC}=$ cubital cell).

the projection of the Procrustes superimposed coordinates onto the linear tangent space at the consensus location (Rohlf, 1999). Due to the large number of variates and in order to maximize the power of the analyses, the dimension of the shape space was reduced using principal components, following the approach detailed in Baylac and Friess (2005).

\subsection{Microsatellite data compilation}

Frequencies of six microsatellite loci (A7, A28, A113, B124, A24, A88) from a total of 36 populations belonging to $11 \mathrm{~A}$. mellifera subspecies from $\mathrm{A}, \mathrm{M}$, and $\mathrm{C}$ branches were compiled from literature reports. For the $\mathrm{M}$ evolutionary branch, 18 populations of A. m. iberiensis (Miguel et al., 2007) and nine populations of A. m. mellifera (Garnery et al., 1998b) were used. For the A evolutionary branch, one population for each of the following subspecies were used: A. $m$. adansonii from Guinea; $A$. $m$. intermissa, A. m. major, and A. m. sahariensis from Morocco; and A. m. capensis and A. m. scutellata from South Africa. For the $\mathrm{C}$ evolutionary branch, A. m. carnica from Germany, A. m. ligustica from Italy, and A. m. macedonica from Greece were used (Estoup et al., 1995; Franck et al., 1998). The microsatellite data were previously calibrated against each other using reference samples.

\subsection{Statistical analysis}

Preliminary Principal Component Analysis did not reveal the presence of outliers. All specimens were therefore used in Multivariate analysis of variance (MANOVAs) and in Canonical Variate Analyses (CVA). Multiple discriminant analyses were used to estimate the classification rates among localities. All classification rates were estimated 


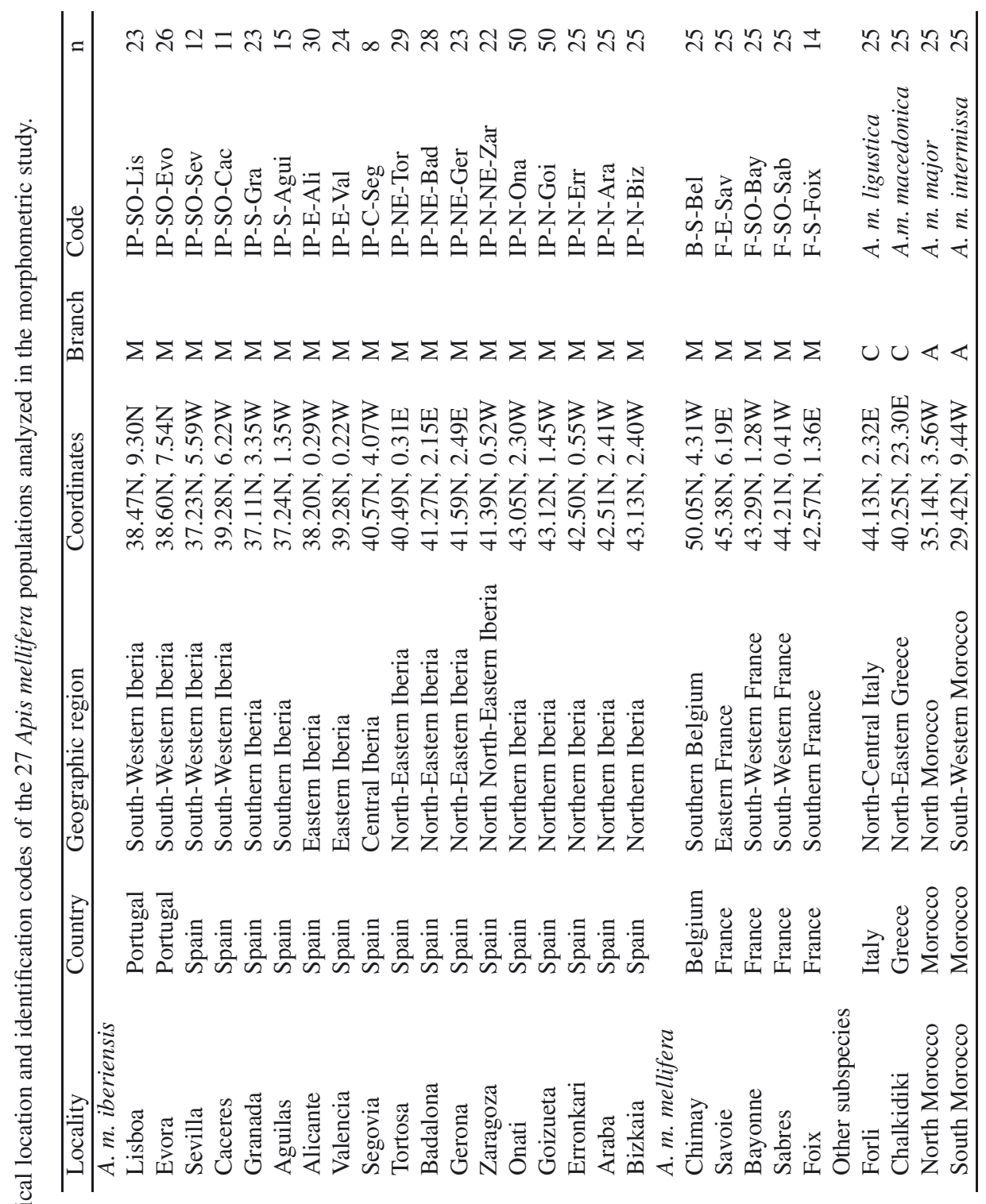




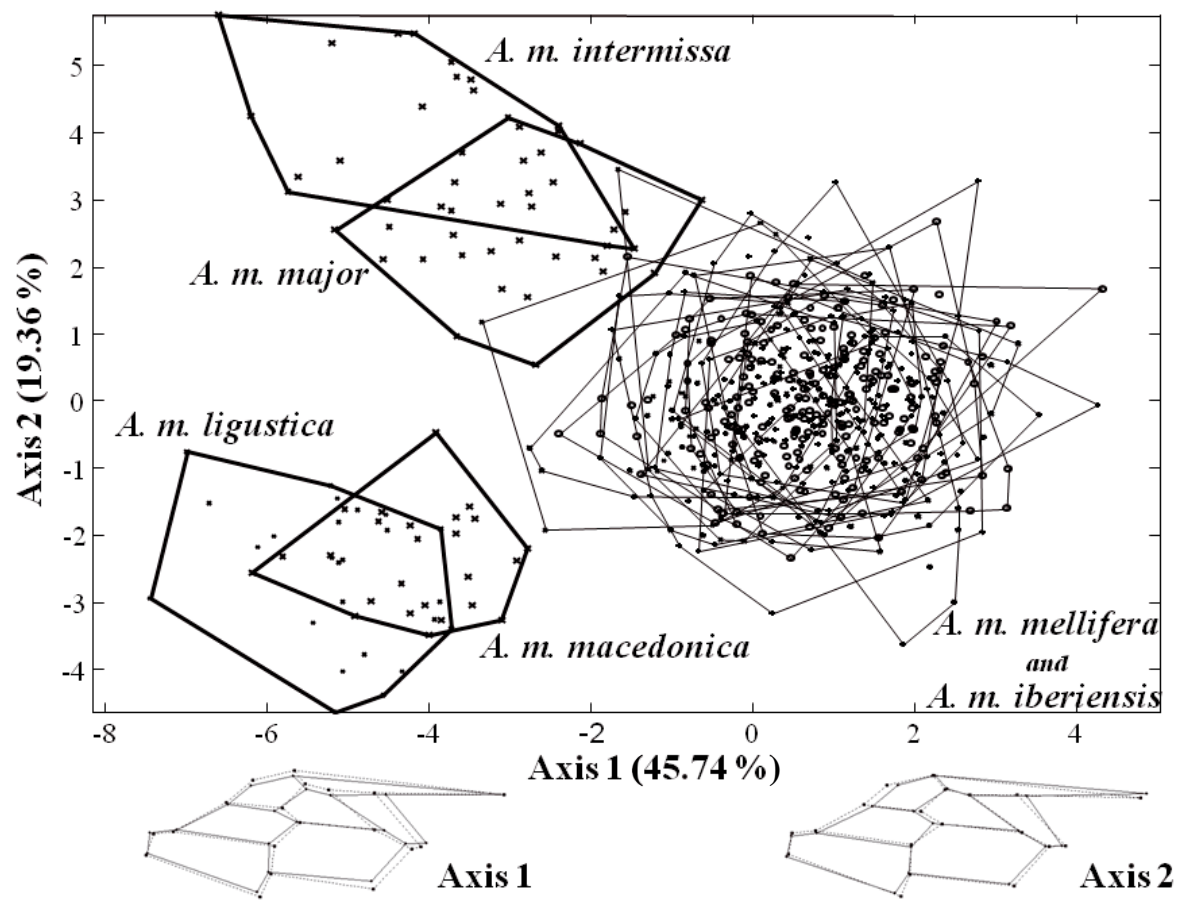

Figure 2. Canonical Variate Analyses of shape (the identification codes of the populations are listed in Tab. I). Shape deformations of the wing along factorial axes 1 and 2 (dotted links for the negative side and solid links for the positive side) were amplified by a factor of 2 for better visualization.

using leave-one-out cross-validations, which provide lower but unbiased estimates (Ripley, 1996). CVA used shape parameters only (i.e., the centroid size parameter was excluded since it never increased significantly the classification rates). Wing deformations along factorial axes were estimated by multivariate regression (Monteiro, 1999) and two extreme shapes were then calculated, one for each axis extremity. Deformations were amplified by a factor of two for better visualizations. We defined a set of links between landmarks in order to help to visualize the overall wing shape. As a rule, the two extreme shapes are drawn using dotted links for the negative side and solid links for the positive side of each axis. To evaluate the morphological relationships among branches $\mathrm{A}, \mathrm{M}$, and $\mathrm{C}$, a neighborjoining (NJ) tree was constructed based on Mahalanobis D2 distances data (Mahalanobis, 1936). All calculations were done using the MATLAB computational environment with the morphometrics toolbox devised by one of us (M.B.).

In order to assess the power of the microsatellites to assign correctly the individuals into their evolutionary lineages and subspecies, two methodologies were used: self-classification of reference data option and a Bayesian approach (Rannala and Mountain, 1997), running Geneclass2 software (Piry et al., 2004). To evaluate the phylogenetic relationship between $\mathrm{A}, \mathrm{M}$, and $\mathrm{C}$ branches, a $\mathrm{NJ}$ tree was constructed on the basis of $\mathrm{D}_{\mathrm{A}}$ distance data (Nei et al., 1983), running Populations 1.2.28 software (Langella, 2002). In order to explore the agreement between morphometric and genetic distance matrices, first-order correlations were calculated. Matrix comparison was carried out by Mantel's method, using ZT software (Bonnet and Van de Peer, 2002) and significance was obtained after 10000 iterations.

\section{RESULTS}

\subsection{Geometric morphometrics}

The first canonical axis (Fig. 2, 45.74\%) separated $\mathrm{M}$ lineage populations from $\mathrm{A}$ and C populations; the second CVA axis $(19.36 \%)$ distinguished $\mathrm{A}$ and $\mathrm{C}$ population branches. 


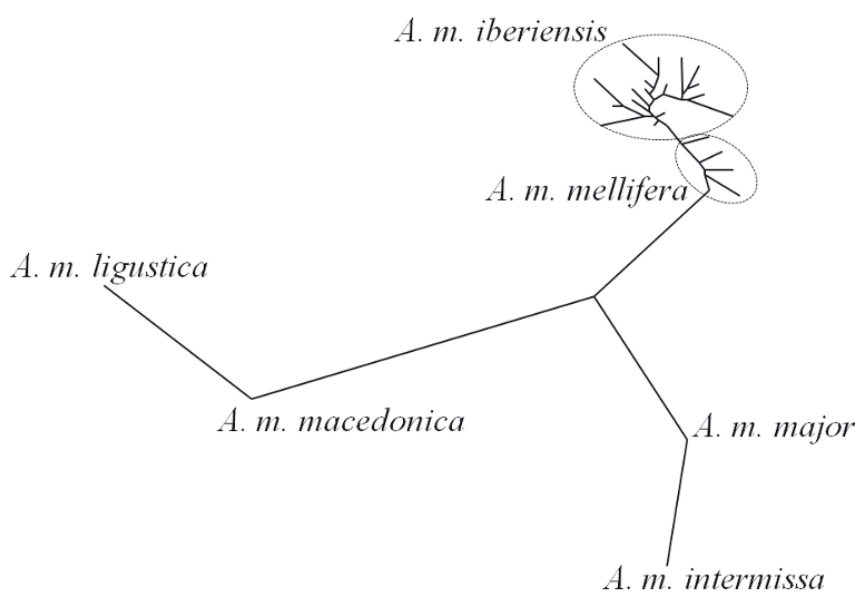

Figure 3. Neighbor-joining tree using the Mahalanobis D2 distance matrix based on geometric morphometric data of the fore wing, using 19 landmarks (see Fig. 1).

The corresponding MANOVA was highly significant (Wilks' Lambda $=0.0144 ; \mathrm{F}=5.818$; $\left.\mathrm{df}_{(11)}=520 ; \mathrm{df}_{(12)}=9902 ; P<10^{-16}\right)$. These CVA patterns are best summarized by a NJ tree calculated from the D2 Mahalanobis distances (Fig. 3): populations from the same evolutionary branch were grouped together, and the three evolutionary branches - A, M, and $\mathrm{C}$ - were clearly separated. Moreover, all honeybee populations from the Iberian Peninsula, A. m. iberiensis, were grouped within the Western European M cluster, which was distant from the $\mathrm{A}$ and $\mathrm{C}$ subspecies clusters. D2 distances were significantly higher between Iberian and North African populations (D2 = 27.56) than between A. m. iberiensis and A. $m$. mellifera $(\mathrm{D} 2=4.70)$.

Leave-one-out cross-validated misclassification percentages, calculated by multiple discriminant analyses, were remarkably low between branches (A-M $=1.14 \%$; $\mathrm{M}-\mathrm{C}=0.16 \%$ ). Wing venation differences observed along the first two canonical variate axes are illustrated in Figure 2, whereas pairwise comparisons between $\mathrm{M}, \mathrm{C}$, and A lineages are depicted in the Figure 4. On the whole, the differences are spread over the whole wing surface, a result which indicates the lack of any strict location of differences, though evolutionary branches differ by opposite relative proportions of the basal and distal regions of the wing. The lack of any location applies equally to most cells, with the possible exception of the basal cell with three landmarks $(4,5$, and 7$)$, which exhibit relatively low variability. All remaining cells contribute to the overall differences. This is particularly evident for cubital cells, which exhibit particularly complex patterns (Fig. 4). Although classical differences between M-C lineages on the cubital cell are clearly retrieved from the geometric morphometric visualizations, it is nonetheless evident that simple ratios such as the cubital index are unable to extract all the pertinent differences contained in the cubital cell landmarks.

\subsection{Microsatellite results and correlations between genetic and geometric morphometric data}

Misclassification percentages of individuals between branches using six microsatellites were low. Only $1.19 \%$ of M individuals were classified into $\mathrm{C}$, and the same percentage was classified incorrectly within the A branch. The percentage of $\mathrm{A}$ branch individuals assigned to $\mathrm{M}$ branch and $\mathrm{C}$ to $\mathrm{A}$ branch was $4.8 \%$. Finally, $2.41 \%$ of $\mathrm{C}$ branch honeybees were 
(I)

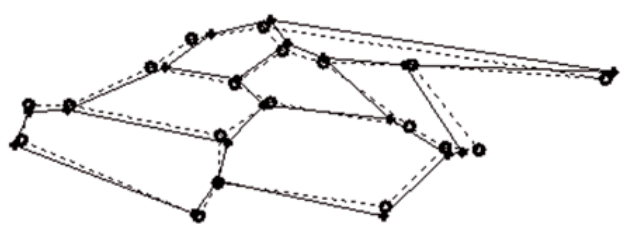

(II)

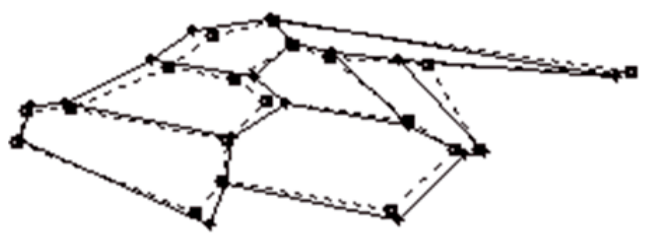

(III)

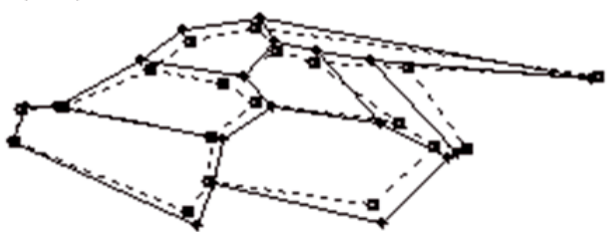

Figure 4. Patterns of fore wing differences between branches. Pairwise comparisons between (I) A-M branches (A solid link and $\mathrm{M}$ dotted link), (II) A-C branches (A dotted link and $\mathrm{C}$ solid link) and (III) $\mathrm{M}-\mathrm{C}$ branches ( $\mathrm{M}$ dotted link and $\mathrm{C}$ solid link).

classified within $\mathrm{M}$ and $1.80 \%$ of $\mathrm{A}$ individuals were assigned to the $\mathrm{C}$ branch. The genetic distance tree clearly discriminated the three branches (Fig. 5). Populations were clustered according to their branches, with the Iberian populations being grouped within the M branch and separated from A. m. intermissa. Moreover, Iberian populations were connected with African ones through French and Belgian A. m. mellifera populations. Correlation values between the molecular and morphological distance matrices (the Nei $\mathrm{D}_{\mathrm{A}}$ vs. the Mahalanobis D2 distances) were highly significant. When the 27 populations were analyzed together, a correlation of $\mathrm{R}=0.9212$ (Mantel test, $P<0.0001)$ was obtained. Considering only $\mathrm{M}$ branch populations, the correlation value decreased but was still highly significant $(\mathrm{R}=0.6566$; Mantel test, $P<0.0001)$.

\section{DISCUSSION}

This study not only clarifies the controversy regarding the relationship between $\mathrm{M}$ and $\mathrm{A}$ branch subspecies, it also demonstrates the overall agreement between geometric morphometrics and nuclear marker data. Moreover, these results highlight the usefulness of geometric morphometrics applied to wing-shape analysis for the individual classification of honeybees within A, M, or C branches. More complete and formal analyses including more lineages and populations are still needed before being able to conclude about its classificatory value. However, in our present results, it appears more than only marginally better, as already stated by Tofilski (2008).

Geometric morphometric results from this study do not corroborate previous studies using traditional morphometrics (Ruttner et al., 1978; Ruttner, 1988; Cornuet and Fresnaye, 1989). Wing shape analysis through geometric morphometrics does not reflect a clinal transition between the A. m. intermissa, A. $m$. iberiensis, and A. m. mellifera subspecies. On the contrary, they show a marked break between North African and Western European populations. This finding is consistent with the conclusions of previous genetic studies using microsatellites and SNPs (Franck et al., 1998; Garnery et al., 1998b; Whitfield et al., 2006) and with the results of Arias et al., (2006) based on classical morphometrics mostly using wing characters. A similar result was also reported by Hepburn and Radloff (1996), though the methodology used (CVA on grouped populations) seems largely questionable when applied to population mixtures and hybrids (Neff and Smith, 1979).

Discrepancies between the results of studies based on traditional and geometric morphometrics, and even between the different quantitative approaches which have been used in the previous characterizations of honeybee diversity, can be ascribed to the choice of different character suites and to the nature of the markers employed: traditional morphological 


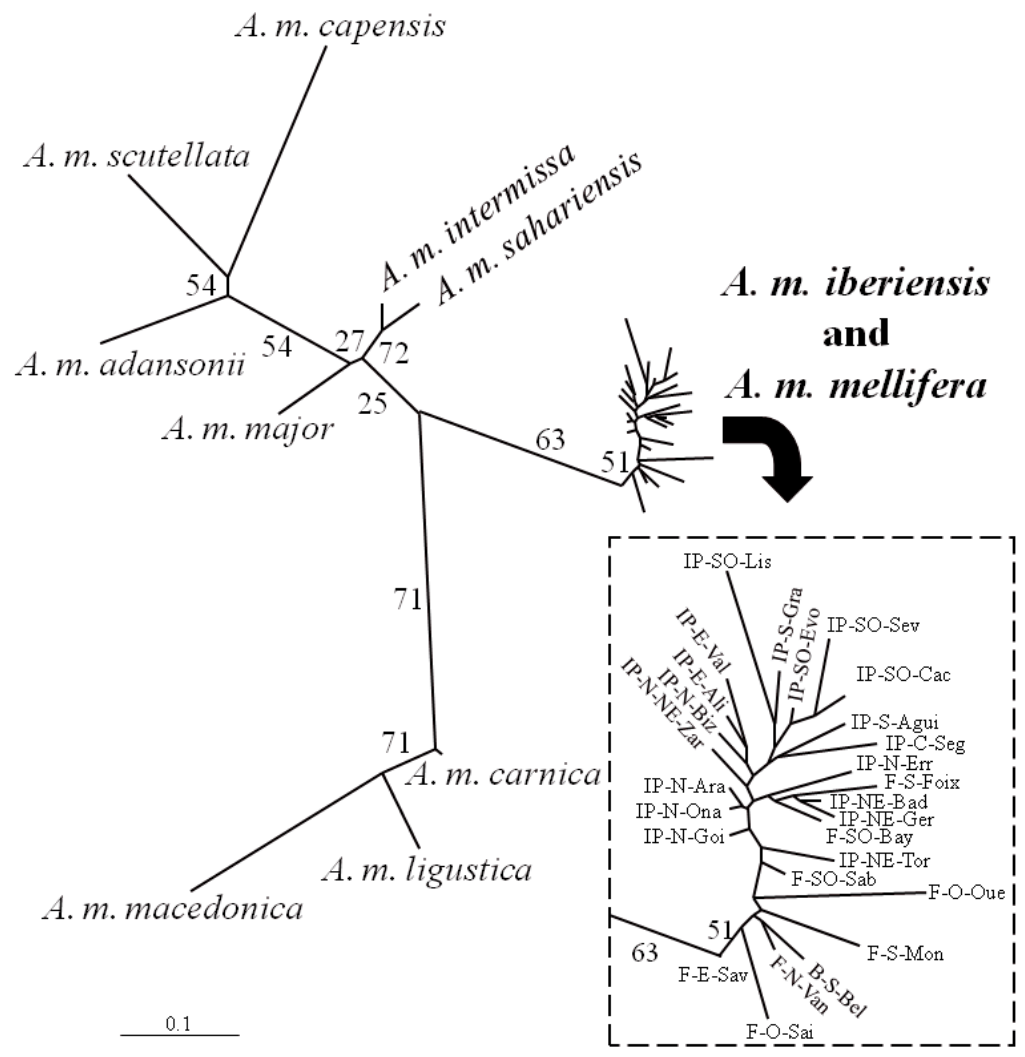

Figure 5. Neighbor-joining tree (bootstrap with 1000 iterations (A7, A28, A113, B124, A24, A88) using $\mathrm{D}_{\mathrm{A}}$ distance matrix (Nei et al., 1983) based on data from 6 DNA microsatellite loci of populations of A, M, and C evolutionary branches (Estoup et al., 1995; Franck et al. 1998; Garnery et al., 1998b; Miguel et al., 2007). The identification codes of the populations are listed in Table I.

studies include a number of characters that are environmently sensitive, such as pigmentation, size, and length characteristics, which are not appropriate for phylogeographic or phylogenetic studies. Measurement of color, body size, hair, proboscis, and hind legs were found to be highly correlated with geographic latitudes (Hepburn and Radloff, 1998; Diniz-Filho et al., 1999; Ruttner et al., 2000). Similar correlations exist among other characters and altitude (Mattu and Verma, 1983; Ruttner, 1988; Meixner et al., 1989, 1994). Although different approaches can be carried out in evolutionary studies, neutrality to the environment should be the primary quality of the selected markers (Franck et al., 1998). In this sense, wings of insects in general and honeybees in particular constitute adequate markers to investigate the patterns of evolution (Baylac et al., 2003). Up to now, many publications using geometric morphometrics of Hymenoptera forewings (Smith et al., 1997; Klingenberg et al., 2001; Pretorius, 2005; Francoy et al., 2006, 2008; Baylac et al., 2003) have shown its great interest when investigating asymmetry, population differentiation, hybridization, and species complexes. Roberts (1961) observed high heritability for wing width and cubital index, and Ruttner (1988) reported that wing venation was a rich source for genetic and taxonomic analyses. Diniz-Filho et al. (1999) show that wing angles are correlated to phylogeny rather than to geography, while the reverse was true in characters such as 
size or color. Thus, wing characters are more appropriate to resolve the question of phylogenetic branch membership, irrespective of traditional or geometric measurement/analysis method. Finally, three main points explain the greatest statistical and interpretative power of geometric morphometrics (Bookstein, 1991; Adams et al., 2004): (1) the more precise descriptions of forms achieved using homologous locations, (2) the use of coordinates instead of distances, ratios, or angles, leading to more exhaustive descriptions of geometric forms (Bookstein, 1991), and (3) the splitting of forms into size and shape parameters that are optimal sensu (Darroch and Mosimann, 1985; Mosimann and James, 1979; Bookstein, 1990; Dryden and Mardia, 1998). The interest of using data that are independent of (body) size to characterize races was already pointed out by Ruttner et al. (1978). But independence between size and shape is an exception in biology (Gould, 1966; Sprent, 1972; Bookstein et al., 1985). Mosimann's framework offers a proper modus operandi to separate size and shapes parameters that results in coherent and powerful statistical analyses of geometric approaches, and it explains also why previous empirical approaches using ratios led frequently to incongruous results.

This study revealed a high consistency between morphological and genetic data. Distance matrices based on both geometric morphometrics and genetic data were found to be highly correlated. Wing-shape data analysis (CVA, NJ tree and the percentage of misclassified individuals) and microsatellite analysis (NJ tree) reflected an almost complete differentiation between the three population groups corresponding to the $\mathrm{A}, \mathrm{M}$, and $\mathrm{C}$ branches. These observations shed fresh light on previous controversies dealing with the origin and phylogeographic position of A. m. iberiensis. Both geometric morphometrics and microsatellite data revealed that A. m. iberiensis is close to A. m. mellifera, and that both are distant from the African subspecies. All these results reject the hypothesis by Ruttner et al. (1978) of a progressive transition of a chain of races between A. m. intermissa, A. $m$. iberiensis, and A. m. mellifera subspecies, as well as the proposal by Smith et al. (1991) of a hybridization process between A. m. mellifera and $A$. m. intermissa as an explanation for the origin of $A . m$. iberiensis. In other words, the existence of a close evolutionary relationship between A. m. iberiensis and A.m. intermissa seems unlikely.

Concerning the presence of African A mitotypes in A. m. iberiensis, the differences detected between Iberian and North African A mitotypes, together with the higher mitotype diversity in Iberia, suggest various introduction events of African mitotypes from different origins or an ancient introduction and subsequent differentiation (Garnery et al., 1992, 1998a; Arias et al., 1996; Sheppard et al., 1997; Franck et al., 1998; Miguel et al., 2007; Canovas et al., 2007). Our results of wing shape and nuclear data did not detect this African influence, indicating that the hypothetical African genetic introgressions seem to have been diluted in the Iberian population. Because genetic introgression between populations of the African evolutionary branch and A. m. iberiensis was only detected in the mitochondrial DNA of the latter subspecies, the propagation of the A lineage mitotypes may well be related to an environmental advantage (Franck et al., 1998; Garnery et al., 1998b; Canovas et al., 2007). However, the higher swarming tendency of African honeybee queens (Ruttner, 1988) may also have exerted an influence on the propagation of their mitochondrial material into southern Europe. In this sense, it is known that the diffusion of the African mitochondrial genome into the Americas does not necessarily correspond to the Africanization of the nuclear genome (Lobo and Krieger, 1992).

Finally, our morphometric results assigned individuals to their correct evolutionary branch, even if they had an A lineage mitochondrial haplotype and European M branch nuclear alleles. For this reason, the geometric morphometric methodology applied in this study seems more appropriate than the analysis of mtDNA for the screening and identification of the Africanization process of Central and North American honeybee populations. Moreover, this method can be easily automated (Baylac et al., 2008) and therefore it is cost-effective, fast and precise, and provides 
information that reflects the genetic background of honeybee populations.

\section{ACKNOWLEDGEMENTS}

This study was funded by the Basque Government Departments of Agriculture and Fisheries, and Education, Universities and Research and by the INIA, in the "Conservation of the Genetic Resources of Food-Processing Interest" framework of the Spanish national $\mathrm{R}+\mathrm{D}+\mathrm{i}$ plan. (Project No. RZ02-009-C2-1). It is a contribution of the UMS 2700 CNRS and "Plate-Forme Morphométrie" of the "Muséum National d'Histoire Naturelle". We thank the numerous beekeepers and colleagues who provided invaluable assistance with the collection of honey bees for this research project. We are also grateful for comments on this article by two anonymous referees.

Les données obtenues à partir de la géométrie morphométrique et des microsatellites se rejoignent pour soutenir la thèse de la différenciation de la branche évolutive M d'Apis mellifera.

abeille / branche évolutive / morphologie / aile / microsatellite / morphométrie géométrique

Zusammenfassung - Geometrische Morphometrie und Mikrosatellitendaten unterstützen übereinstimmend die Differenzierung der evolutionären M-Linie von Apis mellifera. Westeuropa und Nordafrika sind Kontaktzonen für die evolutionären Linien $\mathrm{A}, \mathrm{M}$ und $\mathrm{C}$ der Honigbiene. Obwohl allgemein Übereinstimmung über die Gültigkeit dieser Linien herrscht, wird die Differenzierung der westeuropäischen Linie M kontrovers diskutiert. Traditionelle Morphometrie und die Analyse von Allozymen und mitochondrialer DNA haben bisher eine enge Verwandtschaft zwischen der der M-Linie zugeordneten Unterart $A$. $m$. iberiensis und den nordafrikanischen Unterarten der A- (Afrikanischen) Linie unterstützt (Ruttner, 1978; Cornuet and Fresnaye, 1989; Smith et al., 1991; Smith and Glenn, 1995; Arias et al., 1996, 2006). Studien auf der Basis von Mikrosatelliten und Einzelnukleotidpolymorphismen (SNPs) haben jedoch klare Unterschiede zwischen den beiden europäischen Unterarten der M-Linie (A. m. mellifera und $A . m$. iberiensis) und den nordafrikanischen Unterarten aufgedeckt (Franck et al., 1998, 2001; Garnery et al., 1998b; Whitfield et al., 2006). Als Beitrag zur Auflösung dieses Widerspruchs haben wir 663 Völker von 6 Unterarten der A, M und C Linie analysiert. Die Flügelform wurde mittels einer geometrisch-morphometrischen Methode analysiert, und die Ergebnisse wurden mit den Resultaten einer Mikrosatellitenanalyse von 6 Loci verglichen. Die morphologischen und genetischen Daten stimmten gut überein. Mit beiden Methoden konnten die drei evolutionären Linien unterschieden werden, und mit beiden Methoden kann eine deutliche Differenzierung zwischen den westeuropäischen Unterarten A. m. mellifera und A. $m$. iberiensis und den nordafrikanischen Unterarten abgesichert werden. Die Ergebnisse unterstützen somit eine klare Differenzierung der Unterarten der M-Linie und bestätigen die Hypothese, dass die Präsenz von A-Linien Mitotypen in iberischen Populationen der Honigbiene wahrscheinlich als Folge von sekundärer Einführung betrachtet werden muss. Dabei ist im zurzeit vorhandenen genetischen Hintergrund in Iberien der afrikanische Einfluss minimal. Durch ihre große deskriptive und statistische Aussagekraft führt die geometrische Morphometrie des Flügels bei der Zuordnung von Individuen zu evolutionären Linien zu einer geringeren Anzahl von Fehlklassifikationen. Sie erscheint daher gegenüber der Analyse von mitochondrialer DNA und traditioneller Morphometrie bei der Überprüfung von Populationen der Honigbiene in Zentral- und Nordamerika zum Verfolgen der Afrikanisierung geeigneter.

Honigbiene / Evolutionäre Linie / Flügelmorphologie / Geometrische Morphometrie / Mikrosatelliten

\section{REFERENCES}

Adams D.C., Rohlf F.J., Slice D.E. (2004) Geometric morphometrics: ten years of progress following the revolution, Ital. J. Zool. 71, 5-16.

Arias M.C., Sheppard W.S. (1996) Molecular phylogenetics of honey bee subespecies (Apis mellifera), Mol. Phylogenet. Evol. 5, 557-566.

Arias M.C., Rinderer T.E., Sheppard W.S. (2006) Further characterization of honey bees from the Iberian Peninsula by allozyme, morphometric and mtDNA haplotype analyses, J. Apic. Res. 45, 188196.

Baylac M., Daufresne T. (1996) Wing venation variability in Monarthropalpus buxi (Diptera, Cecidomyiidae) and the quaternary coevolution of box (Buxus sempervirens L.) and its midge: A Geometrical Morphometric Analysis, in: Advances in Morphometrics, NATO-ASI Series A, Plenum Press, pp. 285-301.

Baylac M., Friess M. (2005) Fourier descriptors, Procrustes superimposition, and data dimensionality: an example of cranial shape analysis in modern human populations, in: Slice D.E. (Ed.), Modern Morphometrics in Physical Anthropology, Kluwer, pp. 145-165. 
Baylac M., Penin X. (1998) Wing static allometry in Drosophila simulans males (Diptera, Drosophilidae) and its relationships with developmental compartments, Acta Zool. 44, 97-112.

Baylac M., Garnery L., Tharavy D., Pedraza-Acosta J., Rortais A., Arnold G. (2008) ApiClass, an automatic wing morphometric expert system for honeybee identification, [online] http://apiclass.mnhn. fr.

Baylac M., Villemant C., Simbolotti G. (2003) Combining Geometric Morphometrics with Pattern Recognition for the investigation of Species Complexes, Biol. J. Linn. Soc. 80, 89-98.

Bonnet E., Van de Peer Y. (2002) ZT: a software tool for simple and partial Mantel tests, J. S. S. 7, 1-12.

Bookstein F. (1991) Morphometric tools for landmark data: geometry and biology, Cambridge University Press, Cambridge.

Bookstein F.L., Chernoff B., Elder R.L., Humphries J.M., Smith G.R., Strauss R.E. (1985) Morphometrics in evolutionary biology: the geometry of size and shape change, with examples from fishes, Academy of Natural Sciences of Philadelphia, No. 15.

Canovas F., De la Rua P., Serrano J., Galian J. (2007) Geographical patterns of mitochondrial DNA variation in Apis mellifera iberiensis (Hymenoptera: Apidae), J. Zool. Syst. Evol. Res. 46, 24-30.

Cornuet J.M., Fresnaye J. (1989) Etude biométrique de colonies d'abeilles d'Espagne et du Portugal, Apidologie 20, 93-101.

Darroch J.N., Mosimann J.E. (1985) Canonical and principal components of shape, Biometrika 72, 241-252.

Diniz-Filho J.A., Fuchs S., Arias M.C. (1999) Phylogeographical autocorrelation of phenotypic evolution in honey bees (Apis mellifera L.), Heredity 83, 671-680.

Dryden I.L., Mardia K.V. (1998) Statistical shape analysis, John Wiley \& Sons.

Estoup A., Garnery L., Solignac M., Cornuet J.M. (1995) Microsatellite variation in honey bee (Apis mellifera) populations:hierarchical genetic structure and test of infinite models, Genetics 140, 679695.

Evin A., Baylac M., Ruedi M., Mucceda M., Pons J.P. (2008) Taxonomy, skull diversity and evolution in a species complex of Myotis (Chiroptera: Vespertilionidae): a geometric morphometric appraisal, Biol. J. Linn. Soc. 95, 529-538.

Franck P., Garnery L., Solignac M., Cornuet J.M. (1998) The origin of west European subspecies of honeybees (Apis mellifera): new insights from microsatellite and mitochondrial data, Evolution 52, 1119-1134.

Franck P., Garnery L., Solignac M., Cornuet J.M. (2000) Molecular confirmation of a fourth lineage in honeybees from Near East, Apidologie 31, 167180.
Franck P., Garnery L., Loiseau A., Oldfroyd B.P., Hepburn H.R., Solignac M., Cornuet J.M. (2001) Genetic diversity of the honeybee in Africa: microsatellite and mitochondrial data, Heredity 86 , 420-430.

Francoy T.M., Prado P.R.R., Gonçalves L.S., da Fontoura Costa L., De Jong D. (2006) Morphometric differences in a single wing cell can discriminate Apis mellifera racial types, Apidologie 37, 91-97.

Francoy T.M., Wittmann D., Drauschke M., Müller S., Steinhage V., Bezerra-Laure M.A.F., De Jong D., Concalves, L.S. (2008) Identification of Africanized honey bees through wing morphometrics: two fast and efficient procedures, Apidologie 39, 488-494.

Francoy T.M., Wittmann D., Steinhage V., Drauschke M., Müller M., Cunha D.R., Nascimento A.M. Figueiredo V.L.C., Simoes Z.L.P., De Jong D., Arias M.C., Gonçalves L.S. (2009) Morphometric and genetic changes in a population of Apis mellifera after 34 years of Africanization, Genet. Mol. Res. 8, 709-717.

Garnery L., Cornuet J.M., Solignac M. (1992) Evolutionary history of the honey bee (Apis mellifera L.) inferred from mitochondrial DNA analysis, Mol. Ecol. 1, 145-154.

Garnery L., Franck P., Baudry E., Vautrin D., Cornuet J.M., Solignac M. (1998a) Genetic diversity of the west European honey bee (Apis mellifera mellifera and A. $m$. iberica). I. Mitochondrial DNA, Genet. Sel. Evol. 30, S31-S47.

Garnery L., Franck P., Baudry E., Vautrin D., Cornuet J.M., Solignac M. (1998b) Genetic diversity of the west European honey bee (Apis mellifera mellifera and A. $m$. iberica). II. Microsatellite loci, Genet. Sel. Evol. 30, S49-S74.

Garnery L., Mosshine E.H., Oldroyd B.P., Cornuet J.M. (1995) Mitochondrial DNA variation in Moroccan and Spanish honey bee populations, Mol. Ecol. 4, 465-471.

Gould S.J. (1966) Allometry and size in ontogeny and phylogeny, Biol. Rev. 41, 587-640.

Hamon L.J., Gibson, R. (2006) Multivariate phenotypic evolution among island and mainland populations of the ornate day gecko, Phelsuma ornata, Evolution 60, 2622-2632.

Hepburn H.R., Radlof S.E. (1996) Morphometric and pheromonal analysis of Apis mellifera L. along a transect from the Sahara to the Pyrenees, Apidologie 27, 35-45.

Hepburn H.R., Radloff S.E. (1998) Honeybee of Africa, Springer, Berlin.

Klingenberg C.P., Badyaev A.V., Sowry S.M., Beckwith N.J. (2001) Inferring developmental modularity from morphological integration: Analysis of individual variation and asymmetry in bumblebee wings, Am. Nat. 157, 11-23. 
Langella O. (2002) Populations, 1.2.28, Copyright (C) 1999, CNRS UPR9034.

Lobo J.A., Krieger H. (1992) Maximum likelihood estimates of gene frequencies and racial admixture in Apis mellifera L. (Africanized honeybees), Heredity 68, 441-448.

Mahalanobis P.C. (1936) On the generalized distance in statistics, Proc. Acad. Natl. Sci. 12, 49-55.

Marroig G., Cheverud J. (2004) Cranial evolution in sakis (Pithecia, Platyrrhini) I: Interspecific differentiation and allometric patterns, Am. J. Phys. Anthropol. 125, 266-278.

Mattu V.K., Verma L.R. (1983) Comparative morphometric studies on the Indian honeybee of the North-west Himalaya 1. Tongue and Antenna, J. Apic. Res. 22, 79-85.

Meixner M., Ruttner F., Koeniger N., Koeniger G. (1989) The mountain bees of the Kilimanjaro region and their relation to neighboring bee populations, Apidologie 20, 165-174.

Meixner M., Sheppard W.S., Dietz A., Krell R. (1994) Morphological and allozyme variability in honey bees from Kenya, Apidologie 25, 188-202.

Miguel I., Iriondo M., Garnery L., Sheppard W.S., Estonba A. (2007) Gene flow within the M evolutionary lineage of Apis mellifera: role of the Pyrenees, isolation by distance and post glacial re-colonization routes in the western Europe, Apidologie 38, 141-155.

Monteiro L.R. (1999) Multivariate regression models and geometric morphometrics: the search for causal factors in the analysis of shape, Syst. Biol. 48, 192-199.

Monteiro, L.R., Bordin B., DosReis S.F. (2000) Shape distances, shape spaces and the comparison of morphometric methods, TREE 15, 217-220.

Monteiro L.R., Diniz-Filho J.A.F. dos Reis S.F., Araújo E. (2002) Geometric Estimates of Heritability in Biological Shape, Evolution 56, 563-572.

Mosimann J.E., James F.C. (1979) New statistical methods for allometry with application to Florida red-winged blackbirds, Evolution 33, 444-459.

Neff N.A., Smith G.R. (1979) Multivariate Analysis of Hybrid Fishes, Syst. Zool. 28, 176-196.

Nei M., Tajima F., Tateno Y. (1983) Accuracy of estimated phylogenetic trees from molecular data, J. Mol. Evol. 19, 153-170.

Piry S., Alapetite A., Cornuet, J.M., Paetkau D., Baudouin L., Estoup A. (2004) GeneClass2: A Software for Genetic Assignment and FirstGeneration Migrant Detection, J. Hered. 95, 536539.

Pretorius E. (2005) Using geometric morphometrics to investigate wing dimorphism in males and females of Hymenoptera - a case study based on the genus Tachyphex Kohl (Hymenoptra: Sphecidae: Larrinae), Aust. J. Entomol. 44, 113-121.

Rannala B., Mountain J.L. (1997) Detecting immigration by using multilocus genotypes, Proc. Natl. Acad. Sci. 94, 9197-9221.

Ripley B.D. (1996) Pattern recognition and neural networks, Cambridge University Press, Cambridge, G.B.

Roberts W.C. (1961) Heterosis in the Honey bee as shown by morphological characters in inbred and hybrid bees, Ann. Entomol. Soc. Am. 54, 878882.

Rohlf F.J. (1999) Shape Statistics: Procrustes superimposition and tangent spaces, J. Classif. 16, 197223.

Rohlf F.J., Slice D. (1990) Extensions of the Procrustes method for the optimal superimposition of landmarks, Syst. Zool. 39, 40-59.

Ruttner F. (1988) Biogeography and taxonomy of honeybees, Springer Verlag, Berlin.

Ruttner F., Tassencourt L., Louveaux J. (1978) Biometrical-statistical analysis of the geographic variability of Apis mellifera L., Apidologie 9, 363381.

Ruttner F., Pour-Elmi M., Fuchs S. (2000) Ecoclines in the Near East along $36^{\circ} \mathrm{N}$ latitude in Apis mellifera L., Apidologie 31, 157-166.

Sheppard W.S., Arias M.C., Grech A., Meixner M.D. (1997) Apis mellifera ruttneri, a new honey bee subspecies from Malta, Apidologie 28, 287-293.

Smith D.R., Crespi B.J., Bookstein F.L. (1997) Fluctuating asymmetry in the honey bee, Apis mellifera: effect of ploidy and hybridization, J. Evol. Biol. 10, 551-574.

Smith D.R, Glenn T.C. (1995) Allozyme polymorphisms in Spanish honeybees (Apis mellifera iberica), J. Hered. 86, 12-16.

Smith D.R., Palopoli M.F., Taylor B.R., Garnery L., Cornuet J.M., Solignac M., Brown W.M. (1991) Geographical overlap of two mitochondrial genomes in Spanish honeybees (Apis mellifera iberica), J. Hered. 82, 96-100.

Sprent P. (1972) The mathematics of size and shape, Biometrics 28, 23-27.

Tofilski A. (2008) Using geometric morphometrics and standard morphometrics to discriminate three honeybee subspecies, Apidologie 39, 558-563.

Updegraff G. (1990) MeasurementTV, version 1.3. Data Crunch 304 avenue Adobe, Dan Clemente, CA 92672, USA.

Whitfield C.W., Behura S.K., Berlocher S.H., Clark A.G., Johnston J.S., Sheppard W.S., Smith D.R., Suarez A.V., Weaver D., Tsutsui N.D. (2006) Thrice out of Africa: Ancient and recent expansions of the honey bee, Apis mellifera, Science 27, 642-645. 